\title{
Service productivity: What stops service firms from measuring it?
}

Authors: Gianfranco Walsh, Peter Walgenbach, Heiner Evanschitzky \& Mario Schaarschmidt

Published in: Journal of Organisational Transformation \& Social Change, 13 (1), pp. 5-25, 2016.

DOI:10.1080/14779633.2016.1148890 


\title{
Service productivity: What stops service firms from measuring it?
}

\begin{abstract}
Productivity measurement poses a challenge for service organizations. Conventional management wisdom holds that this challenge is rooted in the difficulty of accurately quantifying service inputs and outputs. Few service firms have adequate service productivity measurement (SPM) systems in place and implementing such systems may involve organizational transformation. Combining field interviews and literature-based insights, the authors develop a conceptual model of antecedents of SPM in service firms and test it using data from 276 service firms. Results indicate that one out of five antecedents affects the choice to use SPM, namely, the degree of service standardization. In addition, all five hypothesized antecedents and one additional antecedent (perceived appropriateness of the current SPM) predict the degree of SPM usage. In particular, the degree of SPM is positively influenced by the degree of service standardization, service customization, investments in service productivity gains, and the appropriateness of current service productivity measures. In turn, customer integration and the perceived difficulty of measuring service productivity negatively affect SPM. The fact that customer integration impedes actual measurement of service productivity is a surprising finding, given that customer integration is widely seen as a means to increase service productivity. The authors conclude with implications for service organizations and directions for research.
\end{abstract}

Keywords: behavioural theory of the firm, measurement, new institutional theory, resources and capabilities, service productivity 


\section{Introduction}

Increasingly competitive service markets force service organizations to look for ways to increase the operational efficiency of service delivery (Ostrom et al., 2010; Prajogo \& Goh, 2007; Ulaga \& Reinartz, 2011). At both conceptual (e.g., Grönroos \& Ojasalo, 2004; Johnston \& Jones, 2004; Sahay, 2005; Parasuraman, 2010) and empirical (e.g., Brown \& Dev, 2000; Lääts, Haldma, \& Moeller, 2011; Rust \& Huang, 2012) levels, growing literature centres on service productivity, generally defined as units of output (e.g., processed customers, sales) divided by units of input (e.g., labour hours) (e.g., López \& Sune, 2013). Despite consensus about the merits of measuring service productivity, the trade press and scholarly articles continue to suggest that service organizations simply do not measure productivity to the extent that manufacturing firms do or measure their productivity without using the results in any meaningful way (Forfás, 2009; Heshmati, 2003; McKinsey, 2006).

It thus appears that some service organizations use productivity measurement as a response to a complex environment which expects organizations to behave in a certain, rationalistic way (Greenwood et al., 2011). In other words, measuring productivity is a way of fulfilling institutionalized expectations and gaining legitimacy (Meyer \& Rowan, 1977). Consistent with the tenets of institutional theory, a service organization may try to gain legitimacy from its internal and external environment by being seen to 'do the right thing' (MacLean and Behnam, 2010), that is, engaging in performance measurement, which is considered to be rational in its environment. Interestingly, although this institutionalized expectation for accountability exists (e.g., Artz, Homburg, \& Rajab, 2012), the literature is inconclusive as to whether performance measurement is associated with firm performance (e.g., Teeratansirikool et al., 2013). The uncertain link between measurement and performance may explain the general reluctance of some service organizations to fully engage in productivity measurement. Another, more technical, reason for the relative lack of 
measurement especially in people-processing services may be the complexity involved in measuring service productivity, particularly the difficulty of modelling the trade-off between changes in productivity (e.g., increasing customer throughput) and key service outcomes such as customer satisfaction (e.g., Anderson, Fornell \& Rust, 1997; Singh, 2000; Wirtz, Chew \& Lovelock, 2012), as well as the difficulty of aligning productivity measures with varying levels of customer integration. The reluctance may also stem from the realization that productivity measurement may require service organization to transform their capabilities and resources (Brynjolfsson \& Hitt, 2000). Beyond the trade-off, we know little about the antecedents of service organizations firms' decisions to measure productivity. This is surprising given that performance measurement continues to be an important topic in organizational practice and research (e.g., O'Cass \& Ngo, 2011; Soltani, van der Meer \& Williams, 2005). Also, in many service industries, efficient service delivery processes are built into business models (Meuter et al., 2005). ${ }^{1}$ Thus, service productivity measurement (SPM) should receive more attention than it currently does. Yet despite the importance of understanding why some service firms do and other service firms do not measure their productivity, organizational and management literature remains anemic on the topic. The accepted link between measuring and managing performance (Kaplan \& Norton, 1996) implies that this research gap may be to the detriment of service organizations.

Complementing previous findings, our study identifies two sets of antecedents that predict SPM: service properties and productivity-related resources and capabilities. Such antecedents are central to understanding why service firms refrain from measuring productivity and also can provide guidance toward overcoming obstacles to measurement. This research therefore aims to make two main contributions. First, we develop a framework of antecedents of SPM based on pertinent literature, institutional theory, and complemented by

\footnotetext{
${ }^{1}$ For example, discount retail chains realize high levels of store productivity by operating stores with few personnel and moving huge volumes through a narrow range of items.
} 
qualitative insights. Second, we test the proposed framework to assess the differential effects of the two sets of antecedents on (1) the decision to engage in some sort of SPM and (2) the degree of SPM, or the extent to which a firm measures the productivity of its service creation activities.

We thus develop our conceptual model by integrating field interviews with literature insights (Gooner, Morgan, \& Perreault, 2011). The data to test the conceptual model come from a sample of 276 service firms. In combination, our results show that only one antecedent, service standardization, affects whether firms measure their productivity, whereas both sets of antecedents affect the degree of SPM for firms that use productivity measurement.

The issues addressed in the present study are relevant for both conceptual and practical reasons. Conceptually, our model and the relationships predicted therein improve understanding of the pathways through which SPM can be increased. The model allows organizational and management scholars to disentangle the effects of different types of antecedents on SPM and provides a basis for further investigations into SPM. Practically, such research is important because it gives service organizations an indication of the disconnect between talk (i.e., SPM is important) and action (i.e., SPM is not fully embraced).

\section{Conceptualization and hypotheses}

Previous research and anecdotal evidence suggest various factors could be responsible for service firms' reluctance to measure their productivity, such as the difficulty of accurately quantifying service inputs and outputs (Johnston and Jones, 2004), finding adequate measurement procedures (Nachum, 1999a), and institutional barriers (Gummesson, 1998). However, no framework draws together potential antecedents of service productivity measures. Considering the universal agreement that measuring productivity enhances business success (Ambler, 2000), such a framework offers multiple benefits: It allows management scholars and practitioners to take a broader, systematic view of the factors that influence a 
service firm's likelihood of measuring productivity, and it illustrates how productivity measurement may be attained by managing its antecedents.

To develop a conceptualization that reflects the interactional nature (between customer and firm) of service delivery and narrow the focus onto the key factors required for a model, we first conducted qualitative fieldwork. Following Gooner, Morgan, and Perreault (2011), we synthesized practitioner and academic literature relevant to SPM. Then we developed an interview protocol based on in-depth discussions with a convenience sample of 15 senior service managers involved in assessing performance in their respective firms (see Appendix 1). These firms come from different service industries. Amongst others, managers were asked whether their firm employed SPM and, where applicable, about their experience with the measures used.

The interview protocol contained open-ended questions and was applied in semistructured, face-to-face depth interviews (Fontana \& Frey, 2005) with 38 senior service managers. These senior managers were recruited with the assistance of a trade association of service firms, and they represented a wide range of service firms from different service industries, ranging from firms with three employees to large multinational service providers with more than 65,000 employees. In addition, we interviewed representatives of chambers of commerce and major trade associations. The interviews covered various aspects of SPM, including the ability of measures to capture varying levels of customer input. Collectively, these interviews helped identify factors for understanding SPM and its antecedents, as well as elicit managers' beliefs in relation to the cause-and-effect relationships among the factors. The results of this qualitative fieldwork show that SPM relates to the type of service offered and the level of customer integration, consistent with early work on service productivity that highlights the critical role of customers' active involvement in service creation for attaining greater service productivity (e.g., Bateson, 1985; Lovelock \& Young, 1979). 
Using the results of the qualitative study, we considered different theories that appeared potentially relevant for exploring the links between SPM and its antecedents. Two theories helped us better understand the results of our interviews and informed the questionnaire development for our quantitative study: the behavioural theory of the firm (for a recent overview, see Gavetti et al., 2012) and new institutional theory (cf. Scott, 2014). Both theories align closely with our fieldwork-based conceptual model, and we used them as theoretical lenses for exploring the theoretical relationships suggested in the conceptual model. First, the behavioural theory of the firm highlights the fundamental decisions of firms about price, output, and resource allocations (Cyert \& March, 1963). By departing from the assumption of rational decision makers, behavioural theory sheds light on how attention allocation in decision making affects the decision outcomes.

Second, institutional theory suggests a sociological view of organizations and their interactions with societal institutions and expectations (Beck \& Walgenbach, 2005; Dacin, Goodstein, \& Scott, 2002). In particular, it focuses on the composition of organizational structures and routines in response to external influences and attempts to explain why many organizations are so similar, a phenomenon known as institutional isomorphism (DiMaggio \& Powell, 1983).

Drawing on new institutional theory, we argue that organizational transformation (e.g., prompted by the decision to engage in SPM) not only aims to help the organization to "compete effectively in its competitive milieu" (Newman, 2000, p. 603) but that the formal structure of organizations is a consequence of changes in external expectations, i.e., of changes of expectations in the field the organizations is operating in. Organizations adopt those structures and practices that are regarded as rational in society general or by important claimant groups of the organization. For example, there is a general belief in western societies that business firms measure and need to measure their productivity. However, departing from 
this basic argument of institutional theory, we state that service firms deviate from this general societal expectation, because of the intangibility of services and greater integration of their customers into service delivery, which make the adoption of service productivity measurement less meaningful.

Although we do not test the behavioural and institutional theories, the present study shows that these considerations help support and inform hypotheses about the constructs we identified in our qualitative fieldwork.

Specifically, the fieldwork-based conceptualization suggests that SPM is influenced by two sets of antecedents: service properties and productivity-related resources and capabilities. Service properties include:

- the degrees of service standardization,

- service customization, and

- customer integration.

Productivity-related resources and capabilities instead feature:

- investments in service productivity gains,

- difficulties in measuring productivity, as well as

- the appropriateness of current productivity measures.

The latter antecedent is only relevant for firms that actually engage in SPM. Therefore, the main antecedents of SPM are capabilities related to SPM, customers and their role in service creation, and the level of resource deployment. This finding ties in with the conventional management belief that firms should deploy resources first to build capabilities that later translate into better performance (e.g., Makadok, 2001). Firms possess tangible and intangible resources and represent a collection of capabilities and routines, all of which relate to firm performance (e.g., Becker, 2005; Teece, Pisano, \& Shuen, 1997). Therefore, differences in firm performance may result from heterogeneous resources, routines, and 
capabilities across firms (Barney \& Arikan, 2001). Organizational routines enable distinctive activities to be performed (Teece, Pisano, \& Shuen, 1997), and SPM constitutes a distinct firm activity.

\section{Service properties}

The field interviews showed that the properties of the service delivered were associated with the degree to which a firm engages in SPM. The most frequently mentioned service properties were the degrees of service standardization, service customization, and customer integration. The interviewees emphasized that the degree of service standardization and the degree of service customization are not opposite ends of the same continuum, as has been posited (e.g., Sundbo, 2002), but actually distinct reasons for (not) measuring service productivity.

The creation of the service can be standardized through service scripts and manuals aimed at regulating employee behaviours, but the delivery and encounters can be customized (Wang et al., 2010). Such standardized-customized service delivery becomes possible, for example, when a service firm uses service scripts but also empowers employees to respond flexibly to customer needs (Heracleous \& Wirtz, 2010). Standardization in service firms appears in the form of manuals, operating procedures, and other blueprints that regulate individual behaviours to control, predict, and minimize mistakes or deviations among employees. Not only is the process under control, but the costs are reduced, and efficiency is maximized through standardization. Increasing service standardization equates to more quantifiable outputs (e.g., number of served customers), which facilitates productivity measurement. Thus:

Hypothesis 1: The degree of service standardization positively affects (a) the choice to measure service productivity and (b) the degree of service productivity measurement. 
To meet customer needs fully, service providers match their offerings to customer preferences (Ghosh, Dutta \& Stremersch, 2006). Thus, the service firm must provide customized attributes, features, and unique delivery methods. Typically, service providers and customers work together to achieve customization (Tuli, Kohli \& Bharadwaj, 2007). However, greater service customization tends to exacerbate the challenge of measuring service productivity though (Wang et al., 2010). A standardized service provision lends itself to SPM because the service inputs and outputs show less variance than do customized services, yet customized service provision cannot be excluded from SPM. Our interviewees noted in particular that customized services tend to involve a larger resource deployment (e.g., employee input), which is why they need to engage in SPM. Deploying resources to SPM created a lock-in situation for these interviewees, in that an increase in investments leads to a greater perceived obligation to engage in productivity measurement, consistent with the notion that higher investments attract more attention from organizational decision makers (Cyert \& March, 1963; March, 1994). According to our interviews and despite the obvious tension with our first hypothesis, we predict:

Hypothesis 2: The degree of service customization positively affects (a) the choice to measure service productivity and (b) the degree of service productivity measurement.

A concept related to but not the same as service customization is customer integration, or the active participation of the customer in service creation. Prior literature advocates customer integration as a means to increase service productivity (e.g., Gouthier \& Schmid, 2003; Lovelock \& Young, 1979; Xue \& Harker, 2002), yet our interviewees suggest that a high degree of customer integration poses a challenge in terms of SPM, because of the difficulty of quantifying customer integration. Not only does customer integration defy measurement with 
extant measurement tools, but it brings about higher costs for the firm's value-creating processes.

Consistent with extant literature, our interviewees stated that customer integration changes existing value-creating processes, so information systems must efficiently handle the intensity and complexity of the interaction (e.g., Duray, 2002; Lee, Barua, \& Whinston, 2000). Customer-firm co-creation creates a situation described as team production in economic theories (Alchian \& Demsetz, 1972). In team production it is difficult, and sometimes impossible, to separate and measure inputs and contributions of individual team members to the output of the overall team. Our interviewees suggested that SPM becomes less likely with increasing customer integration; even when their firms engaged in productivity measurement, customer integration would hamper the degree to which they measured productivity, because of the difficulty of quantifying customer inputs. Thus, with increasing customer integration firms depart from what generally is perceived to be rational in doing business in western societies, namely measuring the productivity of activities. Further, with increasing customer integration they also tend to only loosely couple the measuring of service productivity with the production of services; in other words, they reduce the degree of service productivity measurement. We therefore predict:

Hypothesis 3: The degree of customer integration negatively affects (a) the choice to measure service productivity and (b) the degree of service productivity measurement.

\section{Productivity-related resources and capabilities}

Investments in productivity gains are an import prerequisite for enabling a firm to measure its productivity effectively (Walsh, Enz, \& Canina, 2008). Such investments may be prompted by the degree of resources deployed to create a good or service. In other words, the more resources go into creating a service, the more a firm will attempt to achieve productivity 
gains, because the investments have likely attracted attention from organizational decision makers (Cyert \& March, 1963; March, 1994). Our interviewees listed different paths to increased productivity, such as investments in IT, employee training, or process optimization (e.g., introducing service scripts). This description is consistent with management literature that suggests that firms make investments to improve productivity and firm performance (e.g., Makadok, 2001; Sirmon \& Hitt, 2009). For example, firms invest in IT because it can confer competitive advantages through greater coordination and productivity (e.g., Walsh, Schubert, \& Jones, 2010). Moreover, interviewees stressed that the more resources their firms deploy to service creation, the greater the need to invest in measures to improve productivity.

Although achieving productivity gains is an accepted goal of service management and the concomitant investments generally are considered necessary (Ellinger et al., 2011), service firms do not automatically engage in SPM. In some firms, productivity is not measured until after significant investments in productivity have been made. That is, only after resources have been deployed does the need for SPM arise, because the investments signal managerial commitment, according to several respondents. This observation also is consistent with institutional theory, which suggests that there is a chasm between socially accepted knowledge in the environment of the organization (i.e., SPM is useful) and actions aligned with such knowledge in the organization (Conner \& Prahalad, 1996). Only prompted by substantial investments, a firm may start measuring service productivity. Thus, the chasm can be bridged if firms make commitments, such as investments in service productivity gains, to goals such as SPM. Thus, we predict:

Hypothesis 4: Investments in service productivity gains positively affect (a) the choice to measure service productivity and (b) the degree of service productivity measurement. 
The difficulty associated with measuring service productivity offers a central reason that firms do not employ SPM (e.g., McLaughlin \& Coffey, 1990; Nachum, 1999b; Vuorinen, Järvinen, \& Lehtinen, 1998). This technical difficulty arises primarily from the complexity and heterogeneity of inputs and outputs and the ambiguity of the relationship between input and output. Our field interviews confirmed that service firms face various measurement challenges associated with the unstandardized service delivery, questions about how to assess a successful service delivery, and methods for quantifying the non-time input of employees (e.g., accuracy, empathy), as suggested in prior literature (e.g., Brignall \& Ballantine, 1996; Singh, 2000), which likely explains why SPM is less institutionalized than other forms of performance measurement. Therefore, we posit the following:

Hypothesis 5: The difficulty of measuring productivity negatively affects (a) the choice to measure service productivity and (b) the degree of service productivity measurement.

Finally, most firms appear conscious of the various ways available to measure service productivity. Informants noted the complexity of SPM in terms of quantifying inputs and outputs and acknowledged that the measures they used did not capture that complexity. For example, output should be measured not only in units of service (e.g., served customers, revenue per employee) but also as customer satisfaction, which current measures do not tend to capture. The inadequate measures of service productivity make it less likely that firms assess their productivity or, if they do, measure it to a meaningful degree. Conversely, we expect increased usage of SPM when measures are perceived as appropriate and meaningful. Therefore,

Hypothesis 6: The perceived appropriateness of current productivity measures positively affects the degree of service productivity measurement. 


\section{Method}

\section{Data collection}

We analysed German service firms from different service sectors, so our available sample consisted of more than $1.7 \mathrm{~m}$ service firms, according to the German federal statistical office (Destatis, 2013). The sectors covered in the survey correspond with those included in the German WZ ("Wirtschaftszweige") industry code, which is aligned with the pan-European NACE code. Many of the firms are members of industry associations such as the German Federal Association of Service Firms (BDD). From this sample frame, we drew a random sample of 2,000 firms. The mail surveys, addressed to senior managers, used a standardized questionnaire, which we had developed in cooperation with business partners and pretested. The questionnaire comprised two sections. The first asked respondents to provide firm-related information (e.g., sector, size), and the second contained questions pertaining to the firm's SPM.

The data collection process yielded responses from 292 firms. A response rate of above $14 \%$ is acceptable, given that no incentives were offered and is on par with response rates obtained in other studies using cross-sectional samples of service firms (e.g., Carbonell, Rodriguez-Escudero \& Pujari, 2011). After excluding firms with missing responses, we attained a final sample of 276 firms, many of which came from the financial service sector (n $=69 ; 25 \%)$. We also had firms from the retailing services sector $(\mathrm{n}=43 ; 15.6 \%)$ and tourism, hotel, and restaurant sector $(\mathrm{n}=37 ; 13.4 \%)$. The sample was representative of service firms in Germany (Destatis, 2012).

Nearly all respondents were members of the senior management team, such as executives in commercial and technical areas (40\%), CEOs/general managers/owners (27\%), and department heads (21\%), and thus qualified to respond to the survey. The distribution of firms by size, measured as the number of full-time equivalent employees, indicated that $53 \%$ 
of firms hired between 2 and 250 employees, whereas $47 \%$ had 251 or more employees, and the total average number of employees was 1,366 .

Because we used self-reported data, we conducted several quality checks to ensure the reliability and validity of the data. To reduce non-response bias, we kept the questionnaire relatively short, to minimize the likelihood that respondents would refuse to participate due to time constraints or inconvenience. The data collection took place over a two-week period. Following Armstrong and Overton (1977), we compared the main model variables across early and late respondents, and no statistically significant differences arose.

\section{Measures}

Single-item measures anchored on five-point response scales ( 1 = "disagree fully/very low/inappropriate"; 5 = "fully agree/very high/appropriate") served for all but one variable (i.e., difficulty of measuring productivity), as we depict in Figure 1. These measures helped keeping the questionnaire at a reasonable length and reflected Bergvist and Rossiter's (2007) proposition that constructs consisting of one object can use single-item measures. In addition, Drolet and Morrison (2001) maintain that multi-item measures are neither desirable nor necessary in all cases. Finally, single-item measures yield 'non-psychometric' advantages (see also Fuchs \& Diamantopoulos, 2009). Single-item measures are shorter than multiple-item measures, increasing the likelihood that surveys are completed by respondents, and they take up less space and are more cost-effective because respondents have to take less time out of their workday to complete a survey (Nagy, 2002).

Therefore, to measure the degree of service standardization, we asked respondents to provide a ranking on the item "The service our firm offers is largely standardized"; the degree of service customization item was "To what degree is the service customized to the customer's needs?"; and the degree of customer integration used "To what extent is the customer involved in the service-creation process?" Intended investments in service productivity gains were 
measured with "To what extent is your firm planning to make investments aimed at improving service productivity?" For the measure of the perceived appropriateness of currently employed service productivity measures, we used 'How appropriate do you consider your firm's current productivity measures to be?" However, the difficulty of measuring productivity required an index of the summed responses to six indicators (extracted from qualitative interviews) that captured different aspects of this difficulty: to quantify employee input, to quantify customer input, and to compare delivered services. The means, standard deviations, and correlations are in Appendix 2.

We also included customer type and firm size as co-variables. Customer type refers to whether the firm serves other businesses (B2B) or end customers (B2C); firm size is measured by the number of employees working for a particular firm. By including these control variables, we could avoid the potential for model misspecification had we excluded variables that directly affect the dependent variable.

Figure 1 about here

\section{Results}

As we draw our data from a single source, common method variance (CMV) might bias our findings (Podsakoff, Mackenzie \& Podsakoff, 2012). To reduce the risk of method bias, we employed several procedural remedies before we collected the data (Podsakoff et al., 2003): We pre-tested items for clarity and protected respondents' anonymity to reduce the item characteristic effect. Further, in designing the questionnaire, we ensured that the indicators of the different constructs were in different paragraphs of the questionnaire. By doing so, we reduced the risk of the common-rater effect, the item context effect, and in parts the measurement context effect. After data collection, we followed suggestions from the literature 
and used the "Harman's single factor test" and the "single-method-factor approach" suggested by Podsakoff et al. (2003). Results indicate that CMV is not an issue in our data. ${ }^{2}$

The analysis of our conceptual model includes two steps. In step 1, we investigate the drivers of a firm's decision to engage in SPM, using a logit model. In step 2, we assess firms that engage in some form of SPM and investigate the determinants of the degree of SPM, using a multiple regression model.

The logistic regression including all participating firms $(n=276)$ expressed the predicted values as probabilities and the predicted proportion of firms engaging in SPM as the logistic model $\exp (\mathrm{X}) /(1+\exp (\mathrm{X}))$, where $\mathrm{X}$ is a linear function of the hypothesized independent variables. As the results in Table 1 show, the overall model predicting SPM achieved good fit, as indicated by the change in the $-2 \log$ likelihood from the baseline model (less than .001). The Cox and Snell R-square (.169) and Nagelkerke R-square (.380) both were acceptable, and the Hosmer and Lemeshow measure of overall fit, indicated by the chi-square test of the difference between observed and predicted classification, was not significant $\left(\chi^{2}=2.725\right.$; $\mathrm{df}=$ 8; sig. $=.950)$. Moreover, we can expect $91.3 \%$ of all cases to be correctly classified. Therefore, the overall model fit was acceptable. ${ }^{3}$

Table 1 about here

Table 1 also provides the results for the tests of factors affecting SPM. Surprisingly, only one of the predictor variables, service standardization, increased the likelihood of SPM, in support of H1a. Precisely, a one-unit increase in standardization increased the likelihood of SPM by 1.896 . None of the other predictors affected SPM, and therefore, we must reject $\mathrm{H} 2 \mathrm{a}$, H3a, H4a, and H5a. Finally, though customer type had no effect, firm size was strongly significant; for every additional employee, the likelihood of SPM increased by 1.012.

\footnotetext{
${ }^{2}$ Full details of the analyses are available upon request

${ }^{3}$ To test for model stability, we performed a random split of the sample; the key results remained almost unchanged, though some significance levels dropped slightly.
} 
In the second step, we estimated the predictors of the degree of SPM within firms. Therefore, we only included firms that have engaged in some sort of SPM and excluded those that reported no engagement in SPM, reducing our sample size to 252 firms. To estimate the drivers of the degree of SPM, we ran a multiple regression analysis. The results in Table 2 reveal that that the hypothesized regression model offered a good representation of the empirical data $(\mathrm{F}=14.441, p<.000)$, with reasonable predictive power, considering the nature of the dependent variable $\left(\mathrm{R}^{2}=.322\right)$. Substantively, we found strong support for our hypotheses with respect to the degree of SPM. Standardization exerted the strongest positive impact on the degree of SPM $(\beta=.265, p<.000)$, followed by investments $(\beta=.164, p<.01)$, service customization $(\beta=.156, p<.01)$, and the existence of appropriate measures $(\beta=.154$, $p<.01)$. In contrast, the difficulty of measuring variable had the strongest negative impact ( $\beta$ $=-.197, p<.01)$, and customer integration also showed a negative effect $(\beta=-.162, p<.01)$. These results supported H1b-H5b and H6. Finally, the results were stable across different customer types and firm sizes, as evidenced by the non-significant co-variables.

Table 2 about here

\section{Discussion}

\section{Main findings and implications}

Many organizations subscribe to Kaplan and Norton's (1996, p. 21) adage: "If you can’t measure it, you can't manage it." Some organizations give currency to this adage because they truly believe in it, others to support management legitimacy. Whatever the reason, in service organizations, productivity measures remain challenging. Understanding what facilitates or hinders the measurement of service productivity is vitally important to service firms that want to remain competitive. We used qualitative field research and a survey of service firms from different sectors to investigate the effects of two sets of antecedents on service firms' decisions to measure their productivity and the degree to which they do so. 
Using two regression models, we have identified drivers of service firms' choice to measure service productivity and to what degree. Our first model showed that two service properties (service customization and customer integration) did not affect firms' decision to measure productivity, nor did the difficulty of measuring service productivity. Only service standardization affected the choice to measure service productivity, though a control variable, firm size, also had an impact on the choice to measure service productivity. As institutional theory suggests, organizations likely experience social pressure to adopt practices and routines considered appropriate for a given situation (DiMaggio \& Powell, 1983; Scott, 2008). Our finding that larger service firms are more likely to measure their productivity might imply that larger service organizations experience more prevalent pressure to adopt measurement practices and routines as they are more visible (Beck \& Walgenbach, 2003; Greening \& Gray, 1994). Or perhaps larger service firms are more willing to engage in organizational transformation which involves reshaping routines and behaviours (e.g., Abraham \& Junglas, 2011). The high level of service standardization may enhance service productivity measurement because of the relative ease with which service outputs and inputs can be quantified.

We can confirm the predicted positive effect of investments in service productivity gains when the degree of SPM is the dependent variable, again broadly consistent with institutional theory. Firms that make service productivity-related investments may sense greater institutional pressure to do the right thing and may make decisions aimed at legitimising such investments. Such investments may also increase management's legitimacy to transform the organization in response to societal expectations and in terms of formal structure and management (Leifer, 1989). Furthermore, investment-prone firms may expect to realize technical or economic benefits from measuring productivity. However, the relatively low mean 
values (see Appendix 2) indicate that overall service firms see room for improvement in terms of current productivity measures.

The effects of service properties reveal some interesting differences between the two regression models. Specifically, service customization and customer integration are not related to choices of productivity measurement. The fact that a service firm offers customized services that require customer integration does not mean the firm measures its productivity. Instead, service customization and customer integration negatively affect the degree of SPM. Therefore, firms appear to have trouble matching service productivity measures with services that differ in their firm and customer input. With regard to service standardization, we note a positive effect on choice and degree of SPM. Furthermore, the appropriateness of current productivity measures enhances the degree of SPM, which confirms the notion that effective performance measurement depends on performance measurement systems that mirror the firm's own value-creating activities (e.g., Gunasekaran, Williams, \& McGaughey, 2005). Finally, neither customer type nor firm size affects the degree of SPM.

Our findings, as summarized in Tables 1 and 2, contribute to management literature in three main ways. First, we identify factors associated with service firms' choice and degree of productivity measurement. In so doing, we distinguish service properties, resources, and capabilities, each of which can uncover potential barriers to measuring service productivity. Second, this study actually considers the role of customers with regard to measuring service productivity. Our results indicate that customer integration negatively affects the degree to which service firms measure their productivity. This finding ties in with research that examines potential obstacles to efficient value co-creation with customers (Hoyer et al., 2010). Service management research traditionally has advanced the notion that customer integration in itself can increase productivity. We observe that customer integration reduces the degree to 
which firms measure their productivity, which may point to a lack of performance measurement systems that support variations in customer input. Third, we find that

distinguishing between customer types does not improve the level of SPM explanation. Rather, the type of customer group served has no bearing on whether and to what degree firms measure their service productivity. The results also suggest that firm size relates positively to the decision to measure service productivity, which aligns with research that suggests smaller firms differ from larger firms in many respects, including their resources, structures, workflow, decision-making processes, and levels of hierarchy. Considering these differences, management knowledge developed among large enterprises may not be applicable to smaller firms (e.g., Dandridge, 1979; Julien, 1993). The rationale for measuring productivity thus may differ in smaller firms.

Beyond these contributions, another finding deserves attention. All three service properties and all three resources and capabilities relate significantly to the degree of SPM. As Teece, Pisano, and Shuen (1997, p. 516) define them, capabilities are "the firm's ability to integrate, build, and reconfigure internal and external competences to address" the surrounding environment. Our results suggest that service firms assess the resources they deploy in relation to SPM. Perhaps when firms have decided to make an investment, the system is more likely to be used, because the firms believe they cannot afford to let available resources idle. Some service firms deliberate more over SPM-related investments, but such investments can lead to firm-level benefits (Pollard \& Hayne, 1998).

\section{Limitations and further research}

It is important to recognize the limitations imposed by the study design. First, we used field interviews to enrich insights from current literature and develop our conceptual model, but we cannot rule out the possibility of other antecedents of service firms' service productivity measurements. An in-depth examination of the organizational decision-making 
literature that deals with decision makers' heuristics and rationality could be fruitful. Second, the empirical analyses relied on cross-sectional data from service firms. Although we provide theoretical rationales in support of the directional relationships, we cannot offer statistical evidence of causality. Further studies could employ a longitudinal approach and test for changes in the antecedents and their effects on SPM. Third, we surveyed service organizations about their productivity measurement but did not actually measure productivity or success. Further research could add value in this regard by considering SPM and firm productivity and relating them to firm success. The field interviews similarly suggested that service managers share an understanding of the notion of service productivity, consistent with Bain's (1982) description of productivity as a measure of resource utilization required to achieve specific results. Despite this shared understanding, operational definitions of service productivity might differ from organization to organization, which would influence the way productivity gets measured. For example, some service firms assess productivity by relating quantifiable output to input (e.g., labour hours; Singh, 2000). The degree of consistency between productivity measures could be explored further.

In addition to these directions, several additional research avenues could expand our understanding of SPM. An obvious step is to examine contingencies. Perhaps SPM is less of a concern for new organizations that focus on growing their business and building relationships with their customers. In addition, it would be interesting to determine if SPM relates to different service climates (Mayer, Erhart, \& Schneider, 2009) and corporate cultures. For example, SPM may prevail in service firms with a poor service climate if employees resent the quality degradation associated with cost-saving and productivity-enhancing measures. Increasing customer throughput without increasing staff levels might affect employee wellbeing and overall service. Or SPM may be hampered in organizations with higher levels of team autonomy (Chaston, 1998) where employees favour non-routine service delivery 
processes. The relationships in our model also may be contingent on factors that we did not consider, such as the firm's geographical reach (regional, national, international), mode of service delivery (face-to-face, voice-to-voice, computer-mediated), or knowledge intensity (regular vs. professional services).

Finally, the role of firm size in relation to service productivity deserves more exploration. Our results suggest that firm size relates positively to the choice of SPM but not to the degree to which service productivity is measured. In other words, smaller service firms that measure their productivity do so to the same degree as larger firms. Although we can only offer a preliminary explanation as to why smaller service firms are less likely to measure their productivity, the reasons may emerge from extant literature. That is, smaller firms differ from larger firms on several key characteristics, such as their personalized management, limited devolution of authority, resource limitations, flat and flexible structures, and suffer from a firefighting mentality (e.g., Gélinas \& Bigras, 2004; Hudson, Smart, \& Bourne, 2001; Pullen et al., 2009). However, they are also exposed to institutional pressures to a smaller extent. These characteristics, coupled with substantial investment costs for productivity measurement systems (Neely et al., 1994), may explain why smaller service firms are less likely to measure their productivity. In contrast, larger firms experience more normative pressure, as institutional theory suggests (Ahituv, Igbaria, \& Sella, 1998; Beck \& Walgenbach, 2005; DiMaggio \& Powell, 1983). Decision makers must signal that they are doing the right thing, such as by measuring service productivity even if current measures are flawed. This drive may explain why for larger firms, continuous performance monitoring tends to be more important than it is for smaller firms (Dean \& Kiu, 2002; Ghosh, Dutta, \& Stremersch, 2006).

Considering the importance of performance measurement for improving the management of organizations though, service firms likely can benefit from a better understanding of the antecedents of service productivity measurement. We hope that the 
present study helps facilitate such understanding, as well as encourages further practiceoriented as well as theory-building research (de Jong et al., 2013) into this topic. 


\section{References}

Abraham, C., \& I. Junglas (2011). From cacophony to harmony: A case study about the IS implementation process as an opportunity for organizational transformation at Sentara Healthcare. The Journal of Strategic Information Systems, 20(2), 177-197.

Ahituv, N., M. Igbaria, \& A. Sella (1998). The Effects of Time Pressure and Completeness of Information on Decision Making. Journal of Management Information Systems, 15: 153172.

Alchian, A. A. \& D. Harold (1972). Production, Information Costs and Economic Organization. American Economic Review, 62: 777-795.

Ambler, T. (2000). Marketing and the Bottom Line. The New Metrics of Corporate Wealth. London, UK: Financial Times, Prentice Hall.

Anderson, E. W., C. Fornell and R. T. Rust (1997). Customer Satisfaction, Productivity, and Profitability: Differences between Goods and Services. Marketing Science, 16: 129-145.

Armstrong, J. S. and T. S. Overton (1977). Estimating Nonresponse Bias in Mail Surveys. Journal of Marketing Research, 14: 396-402.

Artz, Martin, Christian Homburg, and Thomas Rajab (2012). Performance-measurement system design and functional strategic decision influence: The role of performancemeasure properties. Accounting, Organizations and Society, 37 (7): 445-460.

Bain, D. L. (1982). The Productivity Prescription. New York, NY: McGraw-Hill.

Barney, J. B. and A. M. Arikan (2001). The Resource Based View: Origins and Implications . In M.E. Hitt, R. E. Freeman and J. S. Harrison (eds), The Blackwell Handbook of Strategic Management, pp. 124-188. Oxford, UK: Wiley-Blackwell.

Bateson, J. E. G. (1985). Self-Service Consumer: An Exploratory Study. Journal of Retailing, 61: 49-76.

Beck, N. and P. Walgenbach (2003). ISO 9000 and formalization - How organizational contingencies affect organizational responses to institutional forces. Schmalenbach Business Review, 55: 294-320.

Beck, N. and P. Walgenbach (2005). Technical Efficiency or Adaptation to Institutionalized Expectations? The Adoption of ISO 9000 Standards in the German Mechanical Engineering Industry. Organization Studies, 26: 841-866.

Becker, M. C. (2005). A Framework for Applying Organizational Routines in Empirical Research: Linking Antecedents, Characteristics and Performance Outcomes of Recurrent Interaction Patterns. Industrial and Corporate Change, 14: 817-846. 
Bergkvist, L. and J. R. Rossiter (2007). The Predictive Validity of Multiple-Item Versus Single-Item Measures of the Same Constructs. Journal of Marketing Research, 44: 175184.

Brignall, S. and J. A. Ballantine (1996). Performance Measurement in Service Businesses Revisited. International Journal of Service Industry Management, 7: 5-31.

Brown, J. R. and C. S. Dev (2000). Improving Productivity in a Service Business: Evidence from the Hotel Industry. Journal of Service Research, 2: 339-354.

Brynjolfsson, E. and L. M. Hitt (2000). Beyond computation: Information technology, organizational transformation and business performance. Journal of Economic Perspectives, 14: 23-48.

Carbonell, P., A. I. Rodriguez-Escudero, and D. Pujari (2011). Customer involvement in new service development: an examination of antecedents and outcomes. Journal of Product Innovation Management, 26: 536-550.

Chaston, I. (1998). Self-managed teams: assessing the benefits for small service-sector firms. British Journal of Management, 9: 1-12.

Conner, K. R. and C. K. Prahalad (1996). A Resource-Based Theory of the Firm: Knowledge versus Opportunism. Organization Science, 7: 477-501.

Cyert, R. M. and J. G. March (1963). A Behavioral Theory of the Firm. Englewood Cliffs, NJ: Prentice Hall.

Dacin, T. M., J. Goodstein, and R. W. Scott (2002). Institutional Theory and Institutional Change: Introduction to the Special Research Forum. Academy of Management Journal, 45: 45-57.

Dandridge, T. C. (1979). Children Are not Little Grown-ups: Small Business Needs its Own Organizational Theory. Journal of Small Business Management, 17: 53-57.

Dean, A. M. and C. Kiu (2002). Performance Monitoring and Quality Outcomes in Contracted Services. International Journal of Quality and Reliability Management, 19: 396-413.

de Jong, F., de Beus, M., Richardson, R., \& Ruijters, M. (2013). Ecologically and Transdisciplinarily Inspired Research: Starting Points for Practitioner Research and Sustainable Change. Journal of Organizational Transformation \& Social Change, 10 (2): 163-177.

Destatis (2013). Statistisches Jahrbuch 2013 für die Bundesrepublik Deutschland. https://www.destatis.de/DE/Publikationen/StatistischesJahrbuch/StatistischesJahrbuch20 13.pdf?_blob=publicationFile, last access 02/11/2014. 
Destatis (2012). Wirtschaftsbereiche: Dienstleistungen.

https://www.destatis.de/DE/ZahlenFakten/Wirtschaftsbereiche/Dienstleistungen/ DienstleistungenFinanzdienstleistungen.html, last access 07/17/2012.

DiMaggio, P. J. and W. Powell (1983). The Iron Cage Revisited: Institutional Isomorphism and Collective Rationality in Organizational Fields. American Sociological Review, 48: 147-160.

Drolet, A. L. and D. G. Morrison (2001). Do We Really Need Multiple-Item Measures in Service Research. Journal of Service Research, 3: 196-204.

Duray, R. (2002). Mass Customization Origins: Mass or Custom Manufacturing?. International Journal of Operations and Production Management, 22: 314-330.

Ellinger, A. E., A. B. E. Bas, A. D. Ellinger, Y.-L. Wang and D. G. Bachrach (2011). Measurement of Organizational Investments in Social Capital: The Service Employee Perspective. Journal of Business Research, 64: 572-578.

Fontana, A. and J. H. Frey (2005). The Interview: From Neutral Stance to Political Involvement . In N. K. Denzin and Y. S. Lincoln (eds), The Sage Handbook of Qualitative Research, 3th edn., pp. 695-728. Thousand Oaks, CA: Sage.

Forfás (2009). Boost Your Company’s Productivity: A Guide for Managers and Employees. http://www.forfas.ie/media/forfas090821_productivity_guide_supporting.pdf, accessed 2012/04/06.

Fuchs, C. and A. Diamantopoulos (2009). Using single-item measures for construct measurement in management research. Business Administration Review, 69: 195-210.

Gavetti, G., H. R. Greve, D. A. Levinthal and W. Ocasio (2012). The Behavioral Theory of the Firm: Assessment and Prospects. Academy of Management Annals, 6: 1-40.

Gélinas, R. and Y. Bigras (2004). The Characteristics and Features of SMEs: Favorable or Unfavorable for Logistics Integration?. Journal of Small Business Management, 42: 263278.

Ghosh, M., S. Dutta and S. Stremersch (2006). Customizing Complex Products: When Should the Vendor Take Control?. Journal of Marketing Research, 43: 664-679.

Gooner, R. A., N. A. Morgan and W. D. Perreault (2011). Is Retail Category Management Worth the Effort? (and Does a Category Captain Help or Hinder?). Journal of Marketing, 75: 18-33.

Gouthier, M. and S. Schmid (2003). Customers and Customer Relationships in Service Firms: The Perspective of the Resource-Based View. Marketing Theory, 3: 119-143. 
Greening, D.W. and B. Gray (1994). Testing a model of organizational response to social and political issues. Academy of Management Journal, 37: 467-498.

Greenwood, R., Raynard, M., Kodeih, F., Micelotta, E. R., \& Lounsbury, M. (2011). Institutional complexity and organizational responses. The Academy of Management Annals, 5(1): 317-371.

Grönroos, C. and K. Ojasalo (2004). Service Productivity: Towards a Conceptualization of the Transformation of Inputs into Economic Results in Services. Journal of Business Research, 57: 414-423.

Gummesson, E. (1998). Productivity, Quality and Relationship Marketing in Service Operations. International Journal of Contemporary Hospitality Management, 10: 4-15.

Gunasekaran, A., H. J. Williams and R. E. McGaughey (2005). Performance Measurement and Costing System in New Enterprise. Technovation, 25: 523-533.

Heracleous, L. and J. Wirtz (2010). Singapore Airlines' Balancing Act. Harvard Business Review, 88: 145-149.

Heshmati, A. (2003). Productivity Growth, Efficiency and Outsourcing in Manufacturing and Service Industries. Journal of Economic Surveys, 17: 79-112.

Hoyer, W. D., R. Chandy, M. Dorotic, M. Krafft and S. S. Singh (2010). Consumer Cocreation in New Product Development. Journal of Service Research, 13: 283-296.

Hudson, M., A. Smart and M. Bourne (2001). Theory and Practice in SME Performance Measurement Systems. International Journal of Operations \& Production Management, 21: 1096-1115.

Johnston, R. and P. Jones (2004). Service Productivity: Towards Understanding the Relationship Between Operational and Customer Productivity. International Journal of Productivity and Performance Management, 53: 33-41.

Julien, P.-A. (1993). Small Business as a Research Subject—Some Reflections on Knowledge of Small Business and its Effect on Economic-Theory. Small Business Economics, 5: 157-166.

Kaplan, R. S. and D. P. Norton (1996). Balanced Scorecard: Translating Strategy into Action. Cambridge, MA: Harvard Business School Press.

Lääts, K., T. Haldma and K. Moeller (2011). Performance Measurement Patterns in Service Companies: An Empirical Study on Estonian Service Companies. Baltic Journal of Management, 6: 357-377. 
Lee, S. C.-H., A. Barua and A. B. Whinston (2000). The Complementarity of Mass Customization and Electronic Commerce . Economics of Innovation and New Technology, 9: 81-110.

Leifer, R. (1989). Understanding organizational transformation using a dissipative structure model . Human Relations, 42 (10): 899-916.

López, L. and Sune, A. (2013). Turnover-induced Forgetting and its Impact on Productivity. British Journal of Management, 24: 38-53.

Lovelock, C. H. and R. F. Young (1979). Look to Customers to Increase Productivity. Harvard Business Review, 57: 168-178.

MacLean, T. L., \& Behnam, M. (2010). The dangers of decoupling: The relationship between compliance programs, legitimacy perceptions, and institutionalized misconduct. Academy of Management Journal, 53(6), 1499-1520.

Makadok, R. (2001). Toward a Synthesis of the Resource-Based and Dynamic-Capability Views of Rent Creation. Strategic Management Journal, 22: 387-401.

March, J. G. (1994). A Primer on Decision Making. How Decisions Happen. New York, NY: The Free Press.

Mayer, D. M., M. G. Ehrhart and B. Schneider (2009). Service Attribute Boundary Conditions of the Service Climate-Customer Satisfaction Link. Academy of Management Journal, 52: 1034-1050.

McKinsey (2006). Measuring Performance in Services. McKinsey Quarterly, http://www.cfo.com/article.cfm/5514575, accessed: 2012/04/06.

McLaughlin, C. P. and S. S. Coffey (1990). Measuring Productivity in Services. Journal of Service Industry Management, 1: 46-64.

Meuter, M. L., M. J. Bitner, A. L. Ostrom and S. W. Brown (2005). Choosing Among Alternative Service Delivery Modes: An Investigation of Customer Trial of Self-Service Technologies. Journal of Marketing, 69: 61-83.

Meyer, J. W., \& Rowan, B. (1977). Institutionalized Organizations: Formal Structure as Myth and Ceremony . American Journal of Sociology, 340-363.

Nachum, L. (1999a). Measurement of Productivity of Professional Services: An Illustration on Swedish Management Consulting Firms. International Journal of Operations \& Production Management, 19: 922-950.

Nachum, L. (1999b). The Productivity of Intangible Factors of Production-Some Measurement Issues Applied to Swedish Management Consulting Firms. Journal of Service Research, 2: 123-137. 
Nagy, M. S. (2002). Using a single-item approach to measure facet job satisfaction. Journal of Occupational and Organizational Psychology, 75, 77-86.

Neely, A., J. Mills, K. Platts, M. Gregory and H. Richards (1994). Realising Strategy through Measurement. International Journal of Operations \& Production Management, 14: 140152.

Newman, K. L. (2000). Organizational transformation during institutional upheaval . Academy of Management Review, 25 (3): 602-619.

O'Cass, A. and L. Ngo (2011). Examining the Firm's Value Creation Process: A Managerial Perspective of the Firm's Value Offering Strategy and Performance. British Journal of Management, 22: 646-671.

Ostrom, A. L., M. J. Bitner, S. W. Brown, K. A. Burkhard, M. Goul, V. Smith-Daniels, H. Demirkan and E. Rabinovich (2010). Moving Forward and Making a Difference: Research Priorities for the Science of Service. Journal of Service Research, 13: 4-36. Parasuraman, A. (2010). Service Productivity, Quality and Innovation: Implications for Service-Design Practice and Research. International Journal of Quality and Service Sciences, 2: 277-286.

Podsakoff, P. M., S. B. MacKenzie, J-Y. Lee and N. P. Podsakoff (2003). Common Method Biases in Behavioral Research: A Critical Review of the Literature and Recommended Remedies. Journal of Applied Psychology, 88: 879-903.

Podsakoff, P. M., MacKenzie, S. B., and Podsakoff, N. P. (2012). Sources of Method Bias in Social Science Research and Recommendations on How to Control It . Annual Review of Psychology, 63: 539-569.

Pollard, C. E. and S. C. Hayne (1998). The Changing Face of Information Systems Issues Facing Small Firms. International Small Business Journal, 16: 70-88.

Prajogo, D. I. and M. Goh (2007). Operations Management Activities and Operational Performance in Service Firms. International Journal of Services Technology and Management, 8: 478-490.

Pullen, A., P. D. Weerd-Nederhof, A. Groen, M. Song and O. Fisscher (2009). Successful Patterns of Internal SME Characteristics Leading to High Overall Innovation Performance. Creativity and Innovation Management, 18: 209-223.

Rust, R. T. and M.-H. Huang (2012). Optimizing Service Productivity. Journal of Marketing, 76: 47-66.

Sahay, B.S. (2005). Multi-factor Productivity Measurement Model for Service Organization. International Journal of Productivity and Performance Management, 54: 7-22. 
Scott, R. W. (2014). Institutions and Organizations: Ideas, Interests, and Identities, 4th ed. Thousand Oaks, CA: Sage.

Singh, J. (2000). Performance Productivity and Quality of Frontline Employees in Service Organizations. Journal of Marketing, 64: 15-34.

Sirmon, D. G. and M. A. Hitt (2009). Contingencies within Dynamic Managerial Capabilities: Interdependent Effects of Resource Investments and Deployment on Firm Performance. Strategic Management Journal, 30: 1375-1394.

Soltani, E., R. van der Meer and T. M. Williams (2005). A contrast of HRM and TQM approaches to performance management: A survey. British Journal of Management, 16, 211-230.

Sundbo, J. (2002). The Service Economy: Standardisation or Customization?. Service Industries Journal, 22: 93-116.

Teece, D., G. Pisano and A. Shuen (1997). Dynamic Capabilities and Strategic Management. Strategic Management Journal, 18: 509-533.

Teeratansirikool, L., Siengthai, S., Badir, Y., \& Charoenngam, C. (2013). Competitive strategies and firm performance: the mediating role of performance measurement. International Journal of Productivity and Performance Management, 62(2), 168-184.

Tuli, K., A. K. Kohli, and S. G. Bharadwaj (2007). Rethinking Customer Solutions: From Product Bundles to Relational Processes. Journal of Marketing, 71: 1-17.

Ulaga, W. and W. J. Reinartz (2011). Hybrid Offerings: How Manufacturing Firms Combine Goods and Services Successfully. Journal of Marketing, 75: 5-23.

Vuorinen, I., R. Järvinen and U. Lehtinen (1998). Content and Measurement of Productivity in the Service Sector: A Conceptual Analysis with an Illustrative Case from the Insurance Business. International Journal of Service Industry Management, 9: 377-396.

Walsh, G., P. Schubert and C. D. Jones (2010). Enterprise System Investments for Competitive Advantage: An Empirical Study of Swiss SMEs. European Management Review, 7: 180-189.

Walsh, K., C. A. Enz and L. Canina (2008). The Impact of Strategic Orientation on Intellectual Capital Investments in Customer Service Firms. Journal of Service Research, 10: 300317.

Wang, G., J. Wang, X. Ma and R. G. Qiu (2010). The Effect of Standardization and Customization on Service Satisfaction. Journal of Service Science, 2: 1-23.

Wirtz, J., P. Chew and C. Lovelock (2012). Essentials of Services Marketing, 2th ed. Singapore: Pearson. 
Xue, M. and P. T. Harker (2002). Customer Efficiency: Concept and Its Impact on E-Business Management. Journal of Service Research, 4: 253-267. 


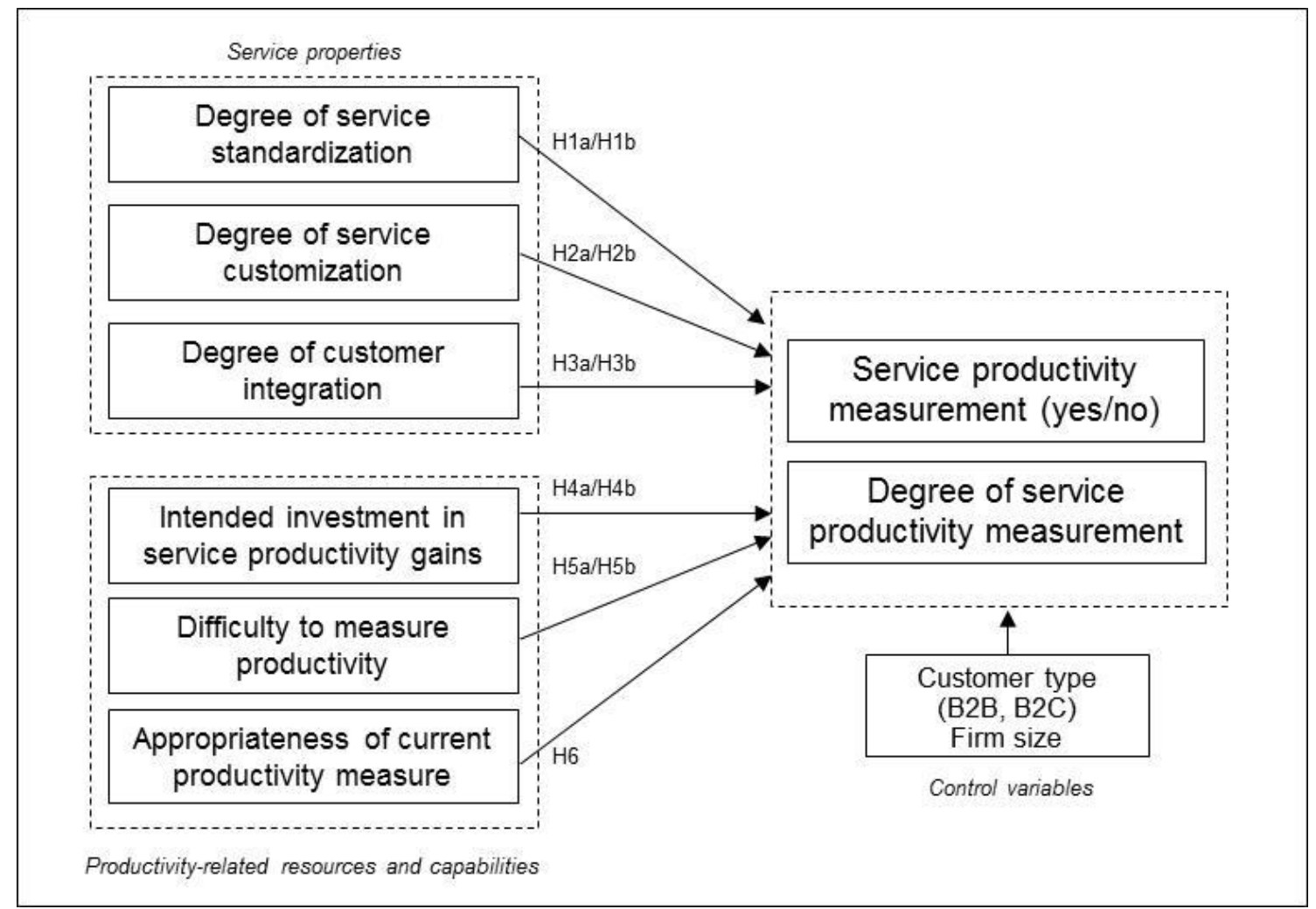

FIGURE 1 Conceptual model 
TABLE 1 Logistic regression results

\begin{tabular}{lccccc}
\hline & B & $\begin{array}{c}\text { Standard } \\
\text { Error }\end{array}$ & Wald & Sig. & Exp(B) \\
\hline Predictor variables & & & & & \\
Service standardization & 0.64 & 0.281 & 5.171 & 0.023 & 1.896 \\
Service customization & 0.262 & 0.262 & 1.004 & 0.316 & 1.300 \\
Customer integration & -0.010 & 0.223 & 0.002 & 0.963 & 0.990 \\
Investments & 0.212 & 0.263 & 0.648 & 0.421 & 1.236 \\
Difficulty to measure & 0.048 & 0.464 & 0.011 & 0.918 & 1.049 \\
& & & & & \\
Co-variables & & & & & \\
Customer type & 0.066 & 0.082 & 0.647 & 0.421 & 1.068 \\
Size (\#)mployees) & 0.012 & 0.004 & 7.236 & 0.007 & 1.012 \\
\hline
\end{tabular}


TABLE 2 Multiple regression results

\begin{tabular}{lccccc}
\hline & B & Beta & t-Value & Sig. & $\begin{array}{c}\text { Variance } \\
\text { Inflation } \\
\text { Factor }\end{array}$ \\
\hline $\begin{array}{l}\text { Predictor variables } \\
\text { Service standardization }\end{array}$ & 0.311 & 0.265 & 4.523 & 0.000 & 1.226 \\
Service customization & 0.188 & 0.156 & 2.689 & 0.008 & 1.205 \\
Customer integration & -0.174 & -0.162 & -2.887 & 0.004 & 1.125 \\
Investments & 0.181 & 0.164 & 2.933 & 0.004 & 1.117 \\
Appropriate measures & 0.245 & 0.154 & 2.704 & 0.007 & 1.167 \\
Difficulty to measure & -0.421 & -0.197 & -3.312 & 0.001 & 1.272 \\
& & & & & \\
Co-variable & & & & & \\
Customer type & 0.022 & 0.064 & 1.180 & 0.239 & 1.071 \\
Size (\#)mployees) & 0.000 & 0.082 & 1.446 & 0.149 & 1.165 \\
\hline
\end{tabular}


APPENDIX 1 Description of informants

\begin{tabular}{|c|c|c|c|c|}
\hline & Name / Gender & Age & Position / Industry & Demographic Details \\
\hline 1 & Alexander / m & 42 & $\begin{array}{c}\text { Managing director / point of sale } \\
\text { software }\end{array}$ & Married, master's degree \\
\hline 2 & Dietrich / m & 43 & Area manager / telecommunications & $\begin{array}{l}\text { Divorced, secondary school } \\
\text { graduation** }\end{array}$ \\
\hline 3 & Ralph / m & 42 & Division manager / insurances & Married, master’s degree \\
\hline 4 & Axel / m & 43 & Managing director / logistics & Married, bachelor's degree \\
\hline 5 & Hartmut / m & 48 & President / Estate agent & Married, high school graduate* \\
\hline 6 & Leonard / $\mathrm{m}$ & 40 & Senior manager / IT consulting & Single, master's degree \\
\hline 7 & Jakob / m & 52 & Director / hotel & Single, bachelor's degree \\
\hline 8 & Henning / $\mathrm{m}$ & 68 & Director / auditing & Married, $\mathrm{PhD}$ \\
\hline 9 & Lucas / m & 36 & Managing director / retailing & Married, master's degree \\
\hline 10 & Stephan / m & 54 & $\begin{array}{c}\text { Branch manager / franchised } \\
\text { restaurant }\end{array}$ & $\begin{array}{l}\text { Married, secondary school } \\
\text { graduation }\end{array}$ \\
\hline 11 & Tanja / f & 38 & Manager / hotel & Single, bachelor's degree \\
\hline 13 & Otto / m & 42 & Manager / bank & Married, bachelor's degree \\
\hline 14 & Rita / f & 38 & $\begin{array}{c}\text { Director / network equipment and } \\
\text { services }\end{array}$ & Divorced, master's degree \\
\hline 15 & Volker / m & 46 & $\begin{array}{c}\text { Managing director / electrical } \\
\text { engineering }\end{array}$ & Married, bachelor's degree \\
\hline
\end{tabular}

Note: $\mathrm{m}=$ male; $\mathrm{f}=$ female. *German equivalent is Abitur. ${ }^{* * G e r m a n}$ equivalent is Realschulabschluss. The real names of informants have been replaced to ensure confidentiality 
APPENDIX 2 Means, standard deviations, and correlations

\begin{tabular}{|c|c|c|c|c|c|c|c|c|c|c|}
\hline & & Mean & $\begin{array}{c}\text { Standard } \\
\text { Deviation }\end{array}$ & 1 & 2 & 3 & 4 & 5 & 6 & 7 \\
\hline 1 & $\begin{array}{l}\text { Investments in service } \\
\text { productivity gains }\end{array}$ & 2.97 & .96 & 1 & & & & & & \\
\hline 2 & $\begin{array}{l}\text { Difficulty of measuring } \\
\text { productivity }\end{array}$ & 2.94 & .51 & $-.27^{* * *}$ & 1 & & & & & \\
\hline 3 & $\begin{array}{l}\text { Appropriateness of current } \\
\text { productivity measure }\end{array}$ & 2.26 & .63 & .12 & $-.21^{* *}$ & 1 & & & & \\
\hline 4 & $\begin{array}{l}\text { Degree of service } \\
\text { standardization }\end{array}$ & 2.93 & .93 & $.16^{* *}$ & $-.24^{* *}$ & $.18^{* *}$ & 1 & & & \\
\hline 5 & $\begin{array}{l}\text { Degree of service } \\
\text { customization }\end{array}$ & 2.50 & .91 & .08 & $.27^{* *}$ & .06 & $-.27^{* *}$ & 1 & & \\
\hline 6 & Degree of customer integration & 3.40 & 1.04 & .10 & $.24^{* *}$ & .06 & $.23^{* * *}$ & $.30^{* * *}$ & 1 & \\
\hline 7 & Degree of SPM & 2.53 & 1.26 & $.33^{* * *}$ & $-.34^{* * *}$ & $.23^{* * *}$ & $.41^{* *}$ & .02 & $-.24^{* *}$ & 1 \\
\hline
\end{tabular}

